\title{
Study on the Problems Existing in Power Enterprise Performance Management and Optimization
}

\author{
Zaixia Ji, Ye Ren, Yuchuan Yang \\ Economy and Trade Department \\ Zhengzhou Electric Power College \\ Zhengzhou,China \\ jizaixai@126.com; yezi11023@163.com; yangyuchuan@163.com
}

\begin{abstract}
With the further development of the national Socialism market economy, the power enterprise management system is improving steadily. It is an important act for the power enterprise to move ahead healthy to strengthen performance management. This paper discusses the significance of power enterprise performance assessment, the problems in the assessment system and the establishment and execution of the system. Base on the analysis of a power bureau, the paper found lots of contradictions and problems especially in performance management and incentive mechanisms building. By making reasonable elements and the method of weighting for the performance evaluation and the corresponding system are established,finally, the statistical data shows that the optimized performance management system is effective and reliable.
\end{abstract}

Keywords- power enterprise; performance management; index; optimization

\section{INTRODUCTION}

Performance appraisal is the premise of effective controllment and stimulation in company management. It is fair competition and encouragement mean for the staff to carry out assessment program, and it provides scientific basis for labour compensation and deployment and utilisation of staff.

The most important task of performance management is to establish Index System of Enterprises achievement evaluation. Firstly, the aim is to improve the management process and insist the principle" Efficiency comes first to balance equity". Secondly, the aim is to make the enterprise management method better and give correct guidance to the value orientation of staff. Finally, it can improve the organizational and personal performance and realize strategic goals of enterprise.

Based on the performance management theories and applying thescientific performance assessment techniques, matching the management strategic targets and human resources situation of some power plant, the thesis designs a suitable performance assessment system, which could be referenced to other domestic power plant. The project includes many parts, such as establishing a all-sided goal system, training system, improving appraisal rules for work outcome and work behavior, strengthening management in basic data for appraisal, diversifying the application of appraisal results.

\section{PROBLEMS EXISTING IN THE POWER ENTERPRISE PERFORMANCE MANAGEMENT}

\section{A. Inaccurate position of performance appraisal}

Appraisal and positioning is not accurate for many electric power enterprises in the performance appraisal, it has no clear goal to solve problems through the assessment and management. Because of the position of performance evaluation is different, it will inevitably lead to different assessment methods, and will have a direct impact on the assessment results and the development goal of enterprises.

\section{B. Performance appraisal index is not clear}

For the different departments of the electric power enterprises, assessment content and assessment standards are different, but in fact, a lot of post evaluation index is not clear, it is difficult to identify, so, it will affect the results of the appraisal, but also may lead to employees cannot combine the responsibilities with the specific target and lead to adverse impact on the enterprise. Performance indicators should include the following content: the complete index name, index, calculation method for index, assessment methods, assessment objective, assessment criteria, assessment period, index information sources and evaluation indexes weights.

\section{Performance assessment approach is not science}

Assessment is an important part of performance appraisal, and will affect the appraisal results directly affect. Therefore, enterprises should explore more scientific way of evaluation according to the actual situation. At present, many power companies affected by the pressure of the market, in the formulation of the performance appraisal system, often emphasize the security, economic and other indicators, and lack of customer feedback, employee learning and skills and other aspects of the examination. In the specific content, assessment methods are unreasonable and unscientific. This way of evaluation, actually has not really play the role of incentives. and will seriously dampened staff's working enthusiasm. 


\section{Performance appraisal has little influence on the rewards and punishments}

In current, after examination,many electric power enterprises did not make the assessment results feedback to the assessment,The staff cannot understand their own situation and with the enterprise development, Performance appraisal has no positive effect on employee job skills, and not give them spiritual and material satisfaction, it will cause the employee dissatisfaction with fairness, and influence the good development of enterprises.

\section{OPTIMIZATION OF POWER ENTERPRISE PERFORMANCE APPRAISAL MANAGEMENT}

\section{A. Construction of Science performance evaluation system}

To build the performance indicators system, it must be a comprehensive analysis of electric power enterprise culture, development goals and the overall quality of management etc. In the aspect of the research on the relationship between performance management and the execution of strategy, wide attention has been paid to Balanced Scorecard (BSC) and Key Performance Indicator (KPI).

\section{B. Comprehensive analysis and build reasonable evaluation index}

Performance appraisal is to reflect the working methods, the employee's work attitude and work performance. Therefore, before the performance evaluation, it is important to carry out a comprehensive analysis about the jobs and responsibilities of the employees, and reasonably determine the content of examination. The performance appraisal index should be consistent with the development objectives and management concept of electric power enterprise, and to consider the different characteristics and specific requirements of each job.

\section{Establish good performance communication mechanism}

Managers and employees should communicate each other about performance, If in the work process, the staff suffered setbacks and failures, they would be encouraged by the concern and support. If their positive performance are timely recognized, it would mobilize their working enthusiasm. Staff obtain their performance through communication, and know how to improved performance. Therefore, continuous communication can timely adjust performance plan to adapt to the changing environment.

\section{Establish and improve the assessment results feedback system}

From the point of view of the managers, it is necessary to timely communicate with the assessment, and then affirm merit, analyse deficiency, make measures and improvement plans to improve. This is equal rights for the organization. From the point of view of the staffs, if the assessment result is unfair, it shall timely start performance results appeal procedures, feedback, complaints against the results, it is also the guarantee of individual rights.

\section{CASE ANALYSIS}

The paper gave out a case about a power bureau post performance management, and analysed its problems and optimized its examination methods.The analysis map of problems existing in the power bureau post are shown as the following figure1.

In order to optimize the performance appraisal system ,the paper adapted two methods: firstly, to quantify, refine indicators, improve assessment methods, secondly, to reform the wage distribution system. And then, the paper analysed the results of implementation of the optimization of performance management. The statistical results compared before and after implementation of assessment are shown as the following table I .

TABLE I. THE STATISTICAL RESULTS COMPARED BEFORE AND AFTER IMPLEMENTATION OF ASSESSMENT

\begin{tabular}{|c|c|c|c|c|c|c|}
\hline $\begin{array}{c}\text { da } \\
\text { ta }\end{array}$ & month & $\begin{array}{c}\text { Copied } \\
\text { rate } \\
(\%)\end{array}$ & $\begin{array}{c}\text { Tariff } \\
\text { recovery } \\
\text { rate } \\
(\%)\end{array}$ & $\begin{array}{c}\text { Rate } \\
\text { of } \\
\text { error } \\
(\%)\end{array}$ & $\begin{array}{c}\text { Meter } \\
\text { reading } \\
\text { number }\end{array}$ & $\begin{array}{c}\text { Other } \\
\text { errors } \\
\text { Deduction }\end{array}$ \\
\hline before & 2009.11 & 94 & 97 & 0.05 & 95327 & 60 \\
\hline \multirow{3}{*}{ after } & 2010.05 & 99.41 & 99.74 & 0004 & 115070 & 40 \\
\cline { 2 - 7 } & 2010.06 & 99.64 & 99.83 & 0.03 & 116594 & 6 \\
\cline { 2 - 7 } & 2010.07 & 99.44 & 99.95 & 0.002 & 118462 & 10 \\
\cline { 2 - 7 } & 2010.11 & 99.89 & 99.94 & 0.002 & 125081 & 4 \\
\hline
\end{tabular}

\section{CONCLUSIONS}

At present, performance appraisal management in the electric power enterprise also has certain problems, it must make scientific examination method,reasonable appraisal content, good test results feedback and communication channels to optimize and improve the core competitiveness .In the implementation process, it should continue the analysis, summarizes and concludes the performance appraisal results, and find out the reasons of performance appraisal of underachievement, and analyse the causes of poor performance, and find the gap about the employees or companies in their areas, and put forward some training.so the performance management will has some practical value, the purpose of performance management can be implemented very well.

\section{REFERENCES}

[1] Zhenbang Fang. Strategic performance management [M]. Beijing: Renmin University of China press,2007.

[2] Shaohua Wang, Xin Liu. The role of electric power enterprise performance evaluation in human resource management $[\mathrm{J}]$. China Electric Power Education,2009,(10):230-231. 
[3] Xin Ma. Study on improvement strategy for Enterprise training effectiveness [J]. China Electric Power Education,2010,(16):214-216.

[4] Tingting Liu, Cunbin Li, Haojie Liu. The construction of performance management system in power enterprises [J]. Human resource management,2010,(12):22-23.

[5] Lei Zhao, Jing Yang. The potential problems and Countermeasures of performance management in power enterprises [J]. China Electric Power Education,2010,(12):239-241.

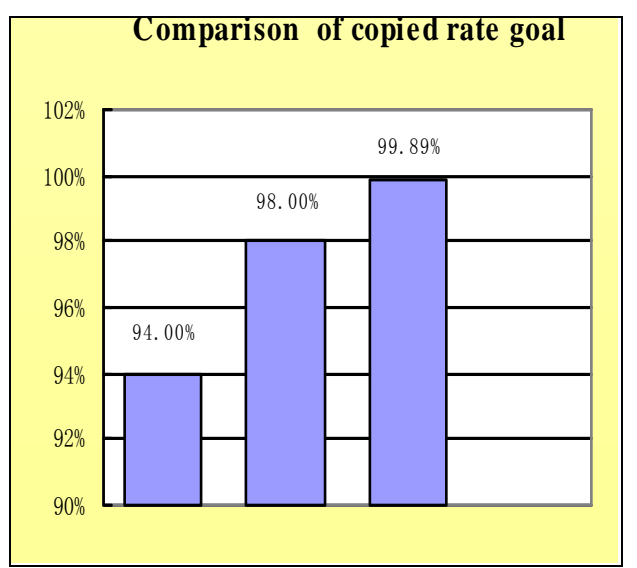

[6] CONWAY, JM. Disting contextual performance from task performance for managerial jobs[J].Journal of Applied Psychology.2011.05.16.

[7] VAN DER VEGT,G..,B.EMANS,ET AL.Team members’ affective responses to patterns of intragroup interdependence and job complexity[J] Journal of Managemnet,2009,26(4):633-655.

[8] BONACICH,PHILLIPS CHNIDER,SHERRY.Communication network,and collective action in social dilemmas:Theoretical issues and research findings[M]W.B.G.Liebrand,D.M.Messick,and H.A.M.Wilke,New York:Pergammon,2011:225-245

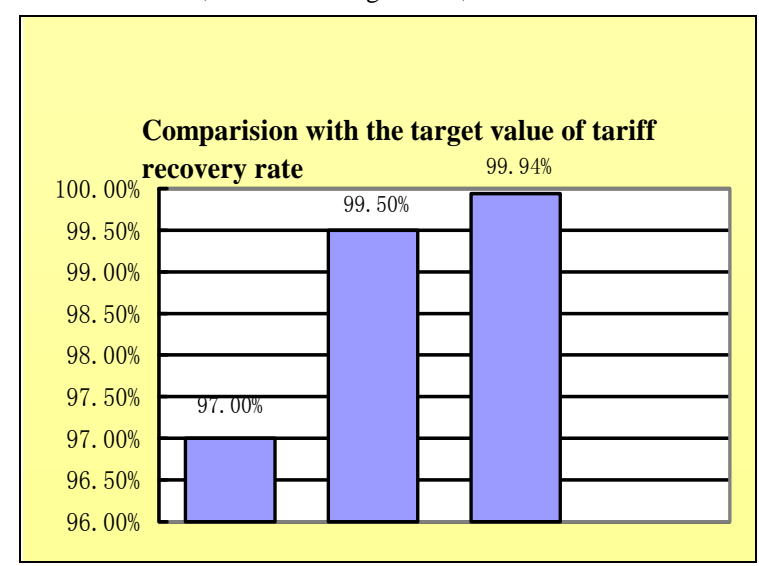

Figure 1. The analysis map of problems existing in the power bureau post
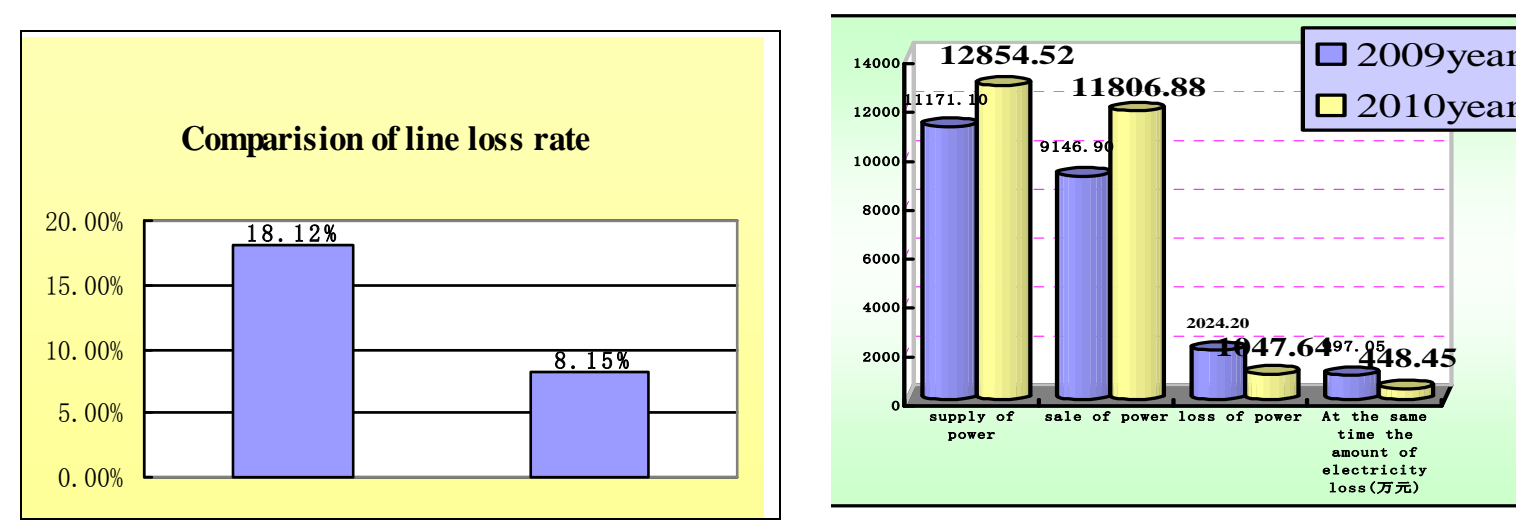

Figure 2. Comparision values of before and after implementation of assessment 